\title{
THE SIGNAL FROM THE CHERNOBYL ACCIDENT IN HIGH-ALTITUDE FIRN AREAS OF THE SWISS ALPS
}

\author{
by
}

\author{
W. Haeberli
}

(Versuchsanstalt für Wasserbau, Hydrologie und Glaziologie, ETH-Zentrum, $\mathrm{CH}-8092$ Zürich, Gloriastraße 37/39, Switzerland)

H. Gäggeler, U. Baltensperger and D. Jost

(E.I.R., Würenlingen, Switzerland)

and

U. Schotterer

(Universität Bern, Physikalisches Institut, $\mathrm{CH}-3012$ Bern, Sidlerstraße 5, Switzerland)

\section{ABSTRACT}

In order to investigate the deposition of radioactive fission nuclides in the high-altitude snow and firn of the Swiss Alps after the Chernobyl accident, core samples from nine mountain peaks were analyzed. The observed radiological signal is described, together with the characteristics of the snow in which it is embedded. Total activity is of the same order of magnitude (around $10 \mathrm{kBq} / \mathrm{m}^{2}$ ) as deposition rates measured at lower altitudes, and shows a comparable regional distribution. A clear altitudinal trend only exists with respect to snow conditions: above about $4000 \mathrm{~m}$ a.s.l., erosion, mixing and resedimentation of cold snow by wind could have occurred during or shortly after the deposition, whereas at lower altitudes formation and percolation of melt water had already started - probably selectively - to redistribute the nuclides within temperate firn layers.

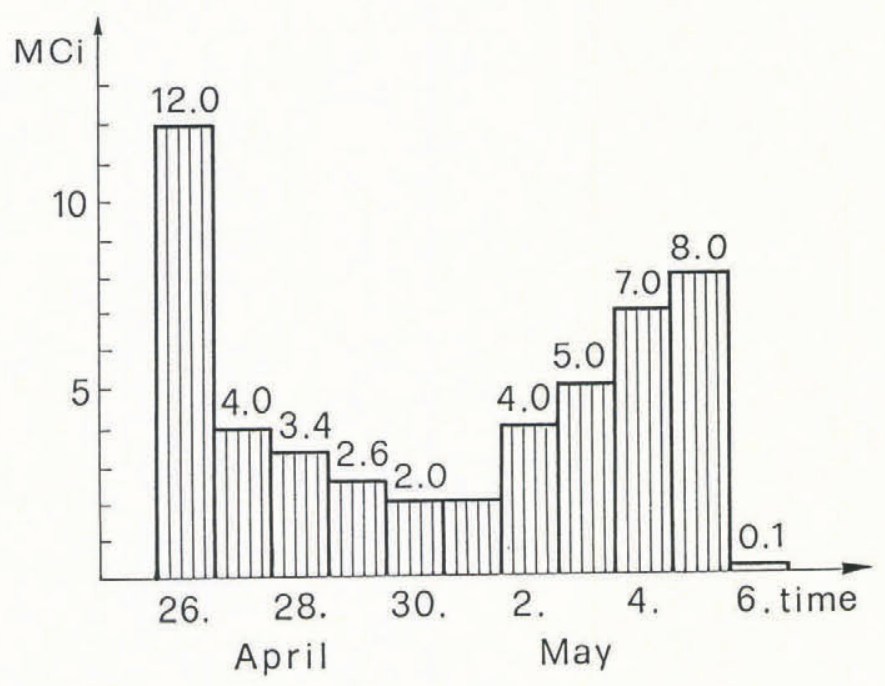

Fig.1. Radioactive delivery from the Chernobyl reactor as a function of time. All activities are related to 6 May 1986. After Bundesamt für Energiewirtschaft (1986), based on Russian information.

\section{INTRODUCTION}

The destruction in spring 1986 of the nuclear reactor in Chernobyl, some $120 \mathrm{~km}$ north of Kiev (U.S.S.R.), induced the explosive delivery of radioactive fission nuclides (Bundesamt für Energiewirtschaft 1986). Between 26 April and 6 May, roughly $50 \mathrm{MCi}$ of radioactive nuclides, together with the total noble gas content, were injected into the atmosphere as a result of the thermal energy developed (Fig.1). During the long-distance transportation of the contaminated air masses, radioactive material must have reached altitudes of up to $8 \mathrm{~km}$. The radiological situation in Europe (Fig.2) was primarily influenced by the wind
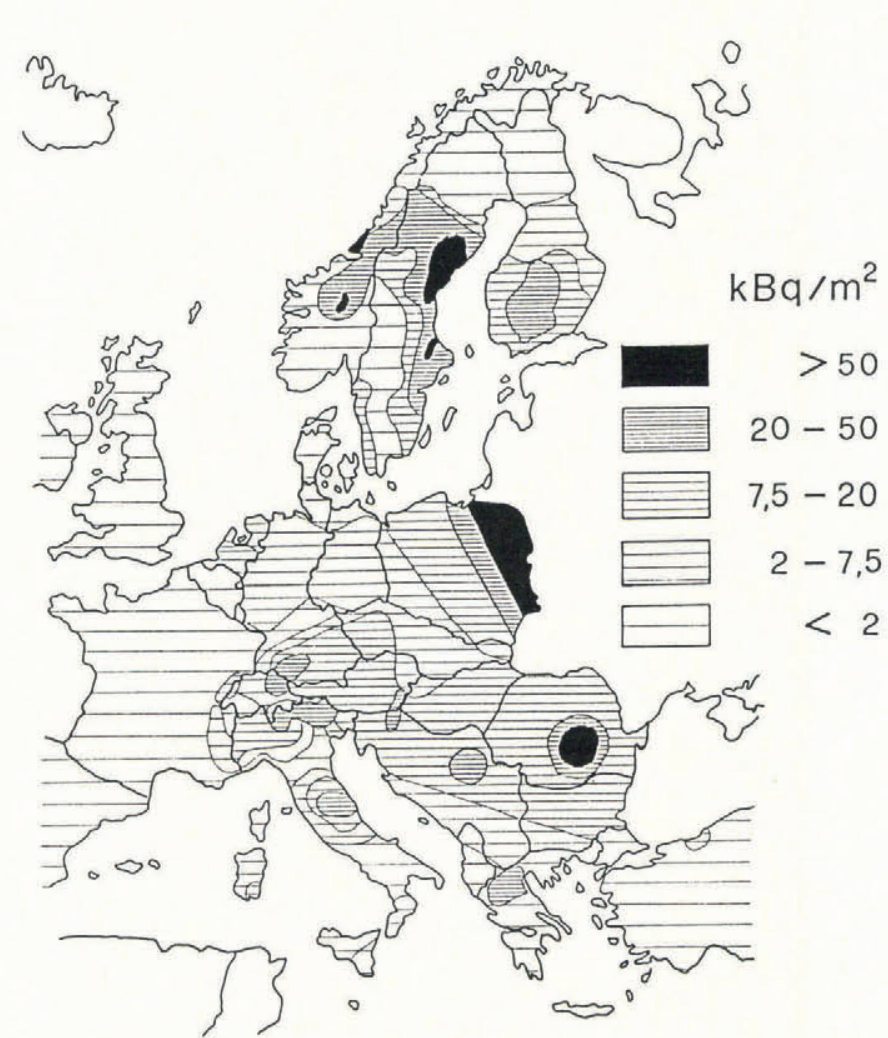

Fig.2. Ground contamination $\left({ }^{137} \mathrm{Cs}\right.$ and $\left.{ }^{134} \mathrm{Cs}\right)$ in Europe after the Chernobyl accident. After Bundesamt für Energiewirtschaft (1986). 
TABLE 1. INFORMATION ABOUT THE SAMPLING SITES (IN CHRONOLOGICAL ORDER)

$\begin{array}{lllllllr}\text { Site } & \text { Coordinates } & \text { Altitude } & \mathrm{T}_{10} & \overline{\mathrm{b}} & \text { Relief } & \mathrm{T}_{\mathrm{S}} & \text { tda } \\ \text { Tödi } & 713.170 / 185.600 & 3540 & -5 & 0-1 & \text { mountain top, slope } & \text { melting } & 1700 \\ \text { Silvrettapass } & 802.250 / 191.810 & 3010 & 0 & 1 & \text { firn divide, saddle } & \text { melting } & 2000 \\ \text { Zupò/Argient (Bernina) } & 791.210 / 138.450 & 3815 & -10 & 0-1 & \text { mountain top, shoulder } & \text { melting } & 7000 \\ \text { Rheinwaldhorn } & 722.875 / 150.640 & 3300 & -2 & 0-1 & \text { mountain top, slope } & \text { melting } & >14000 \\ \text { Weiss Nollen (Rhone) } & 674.050 / 167.290 & 3410 & 0(?) & 0-3 & \text { firn slope } & \text { melting } & 1600 \\ \text { Tête Blanche (Trient) } & 567.500 / 92.425 & 3300 & -3 & 0-1 & \text { mountain top, plateau } & \text { melting } & \sim 470 \\ \text { Grand Combin } & 588.650 / 87.370 & 4125 & -10 & 1 & \text { mountain top, saddle } & \text { cold } & 8800 \\ \text { Colle Gnifetti (Monte Rosa) } & 633.800 / 86.600 & 4455 & -14 & 0.35 & \text { mountain top, saddle } & \text { cold } & 2600 \\ \text { Blinnenhorn } & 666.810 / 142.150 & 3270 & 0(?) & 1 & \text { mountain top, slope } & \text { melting } & >7600\end{array}$

Coordinates and altitudes in $\mathrm{m}, \mathrm{T}_{10}=$ temperature at $10 \mathrm{~m}$ depth $\left({ }^{\circ} \mathrm{C}\right)$

$\overline{\mathrm{b}}=$ mean annual balance in $\mathrm{m}$ w.e.

$\mathrm{T}_{\mathrm{S}}=$ thermal conditions along the recovered core

tda $=$ totally deposited activity $\left(\mathrm{Bq} / \mathrm{m}^{2}\right)$

field and the distribution of precipitation, because wet deposition obviously predominated relative to dry deposition. The overall pattern of air-mass trajectories and precipitation events appears to have been extremely complicated and is not fully understood. In Switzerland, the highest deposition at ground level was measured in the north-eastern and southern parts of the country (Fig.3). Measurements of activity distributions, carried out on size-fractionated aerosol samples from Spiez and Zürich (Jost and others 1986), gave a pronounced maximum for ${ }^{103} \mathrm{Ru}$ and ${ }^{137} \mathrm{Cs}$ between 0.7 and $0.9 \mu \mathrm{m}$ (aerodynamic diameter).

First analyses of a firn core, recovered on 20 May from the Fiescherhornplateau $(3900 \mathrm{~m}$ a.s.1., near Jungfraujoch), indicated that considerable amounts of radio-nuclides had been deposited in high-altitude firn areas of the Swiss Alps. It was therefore decided to carry out a snow- and firn-sampling programme on a number of glacierized mountain peaks. The aim of the study was to document the radiological signal within the uppermost snow

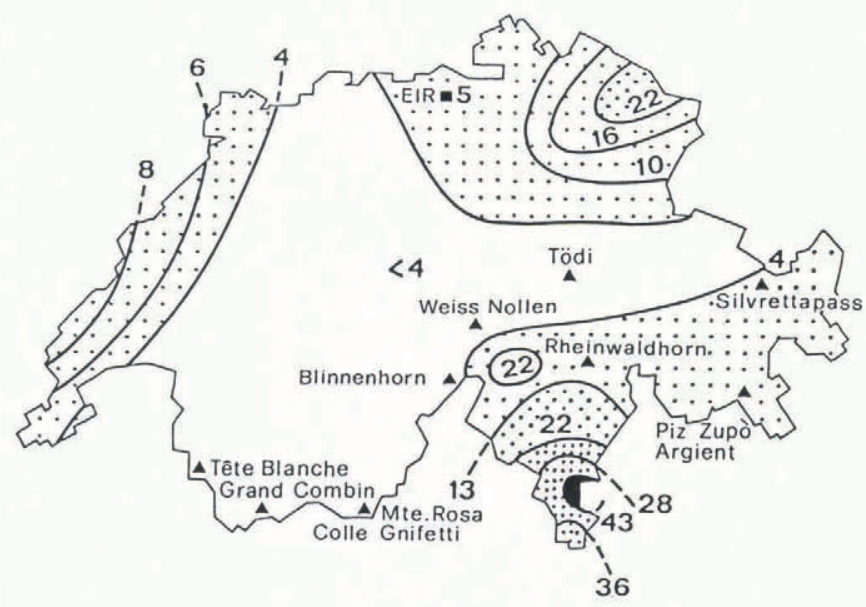

Fig.3. Maximum deposition of ${ }^{137} \mathrm{Cs}$ at ground level in Switzerland $\left(\mathrm{kBq} / \mathrm{m}^{2}\right.$, after Bundesamt für Energiewirtschaft 1986), and high-altitude sampling sites described in this paper. and firn layers. The ablation season and, hence, formation and percolation of melt water had already started in firn areas within the belts of "warm" and "cold" infiltration (cf. Haeberli 1976), below about $4000 \mathrm{~m}$ a.s.l. Above this level, in the "infiltration-recrystallization" belt, snow accumulation is known to be strongly influenced by wind (Haeberli and others 1983, Alean and others 1984). It was therefore to be expected that in addition to regional and altitudinal variability of radioactive precipitation, place-to-place variability in depositional and diagenetic firn conditions would complicate the distribution pattern and the form of the signal embedded in the firn. The present contribution describes and briefly discusses the information collected so far.

\section{SAMPLING SITES AND METHODS}

The main criteria for selecting the sampling sites were (1) to obtain appropriate regional coverage and (2) to investigate regularly deposited and - wherever possible non-temperate snow and firn. Table I summarizes information about the sites investigated (cf. Fig.3). The firn temperature at $10 \mathrm{~m}$ depth was estimated from earlier high-altitude measurements (Haeberli and Alean 1985) and is assumed to correspond roughly to the mean annual firn temperature at the surface. Measured values were available from Colle Gnifetti (Oeschger and others 1978, Blatter and Haeberli 1984). Average values of annual balance (accumulation) were roughly estimated from Schotterer and others (1981) and Gäggeler and others (1983) for Colle Gnifetti, from Kasser and Siegenthaler (1985) for Blinnenhorn/Silvrettapass and from the compilation by Haeberli and Alean (1985) for the other cases.

The Swiss Army made helicopter flights on 1 July (Tödi, Silvrettapass, Zupò/Argient, Rheinwaldhorn, Weiss Nollen) and 4 July (Tête Blanche/Trient, Grand Combin, Colle Gnifetti/Monte Rosa, Blinnenhorn). At each site, firn cores were taken to a depth of $2-3 \mathrm{~m}$ with a hand-operated core drill. At the same time, snow stratigraphy (grain-size, grain shape, hardness, humidity, ice layers) was studied in a shallow pit, using standard techniques. Temperature was measured by thermometers introduced horizontally into the wall of the snow pit and by thermistor probes lowered vertically into the snow/firn and into the bore hole after completion of the core drilling. Thermometer readings are correct within $0.5^{\circ} \mathrm{C}$, but the thermistor probes give less 
accurate results: they may be influenced by vertical heat flow within non-temperate snow/firn, and time in the bore hole was too short for complete thermal equilibration to be established. For these two reasons, the temperatures indicated below $1 \mathrm{~m}$ depth are maximum values only and may in reality be about $1{ }^{\circ} \mathrm{C}$ colder. The core samples were brought to the laboratory and stored in a frozen state. For the analysis, they were cut into sections $10 \mathrm{~cm}$ long. A part of each melted sample was used for beta measurements in a liquid-scintillation spectrometer. Tritium analysis could not be performed because the higher beta energies of the Chernobyl fall-out nuclides influenced the count rates within the tritium window. The count rates given therefore refer to beta energies greater than $15 \mathrm{keV}$. In addition, data have been corrected to allow for the background activity, i.e. they represent the net count rates attributable to Chernobyl nuclides. The measurements were calibrated using a firn sample from the Fiescherhornplateau. The absolute activity of this sample had been determined with a $\mathrm{GeLi}$ detector. The resulting yield with the applied measuring configuration - a cocktail with $10.2 \mathrm{ml}$ water and $12 \mathrm{ml}$ scintillator - was around $90 \%$. A net count rate of $1 \mathrm{cpm}$ therefore corresponds to about $1.5 \mathrm{~Bq} / 1$.

\section{RESULTS}

Figure 4 summarizes the results of the field and laboratory measurements. The observed count rates clearly indicate that all the sampling sites had received radioactive deposition from the Chernobyl accident. Concentrations, however, vary strongly from place to place. Table I presents a comparison of total activity. The highest activity was measured in samples from Rheinwaldhorn, Grand Combin,
Blinnenhorn and Piz Zupò/Argient, which are all sites in the southern and eastern parts of the Swiss Alps. An exception is Colle Gnifetti on Monte Rosa, which geographically belongs to this group too, but which shows astonishingly low activity, especially if compared with the relatively close Grand Combin site at a similar altitude. Core samples from the northern chain of the Alps (Silvrettapass, Tödi, Weiss Nollen) gave distinctly lower values, with a slightly decreasing trend from east to west. By far the lowest activity was measured in the core from the Swiss part of the Mont Blanc group in the extreme west (Tête Blanche/Trient). A general increase in total activity with altitude is not evident within the altitudinal belt investigated $(3000-4500 \mathrm{~m}$ a.s.1.); the regional pattern clearly predominates

The core samples from Colle Gnifetti and Grand Combin, i.e. from altitudes above $4000 \mathrm{~m}$ a.s.l., were taken from dry, cold, fine-grained snow and from firn with few near-surface ice layers. Melt water must have had little influence in these cases, whereas the processes of wind erosion, snow drift, and mixing and resedimentation of surface snow must be assumed to be important and can lead to strong local variability in accumulation patterns. On Grand Combin, the activity peak is higher than on Colle Gnifetti by almost one order of magnitude and the active horizon is thicker by a factor of about 2. This may indicate that individual snow deposits have been preserved better at the Grand Combin sampling site. In addition, precipitation conditions may have differed between the two sites. In both cases, ice layers had formed above the activity peak. It can therefore be assumed that the snow containing the activity peak is now protected against further wind erosion. Because melt-water production and percolation
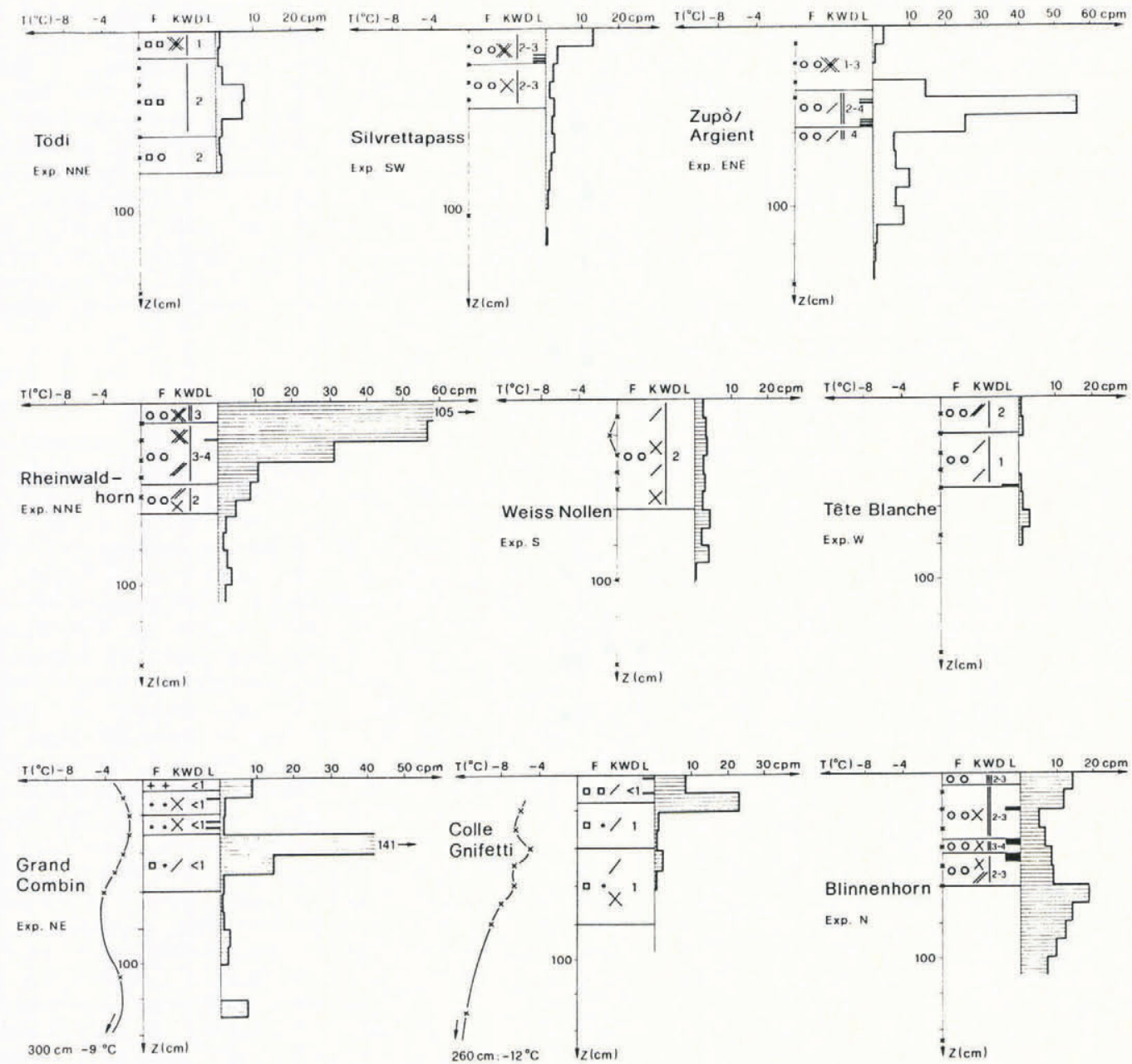

Fig.4. Snow stratigraphy and net count rates as a function of depth for the nine sampling sites. $\mathrm{F}=$ grain shape, $\mathrm{K}=$ hardness, $\mathrm{W}=$ humidity, $\mathrm{D}=$ grain-size in $\mathrm{mm}, \mathrm{l}=$ ice layers and ice lenses, $\mathrm{cpm}=$ count rates per minute. 
is rare at these altitudes, the signal will probably change its shape by the processes of firn compaction only.

Melt-water influence is strong in all core samples taken at altitudes below $4000 \mathrm{~m}$ a.s.l. Snow and firn layers within the uppermost $2-3 \mathrm{~m}$ were at melting temperature and wet. They usually consisted of large and rounded grains and, in some cases, contained a number of well-developed ice layers. The activity signal seems to be smeared out over a considerable depth, despite the high activity in the surface layers. This indicates that ablation had already eliminated some surface snow and that percolation had taken place. In the case of Piz Zupo/Argient, vertical percolation in cold firn is limited and refreezing should take place within deeper firn layers. In principle, the same would be true for Tödi, Tête Blanche/Trient, Rheinwaldhorn and Blinnenhorn. In these cases, however, sampling was done on relatively steep slopes and close to crevasses. It is therefore possible that percolating melt water could follow ice layers parallel to the surface and leave the firn laterally. At Silvrettapass and Weiss Nollen/Rhone, firn is probably temperate and percolating melt water can leave the firn vertically. In all these cases, some radioactive melt water may already have escaped before the sampling.

Due to the fact that the effects of neither wind erosion nor percolating melt water are known exactly, the total activity presented in Table I can only be a rough estimate. It would be possible to study the influence of wind and snow-drift on Colle Gnifetti, where accumulation varies within short distances (Alean and others 1984). To investigate the effect of melt-water percolation, some profiles of individual nuclides were analyzed using gammaspectroscopy. First results from analysis of the two main

\section{Piz Zupò/Argient}
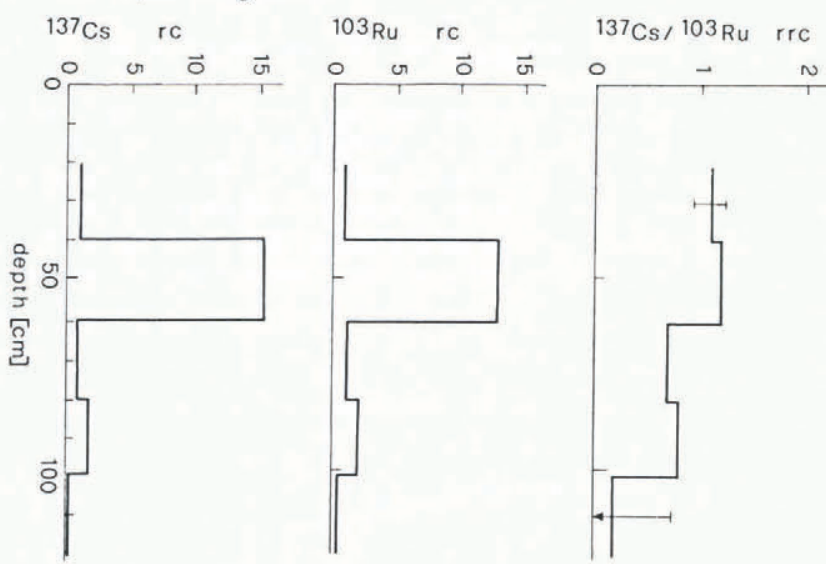

EIR-C5 $-86-32$

\section{Blinnenhorn}
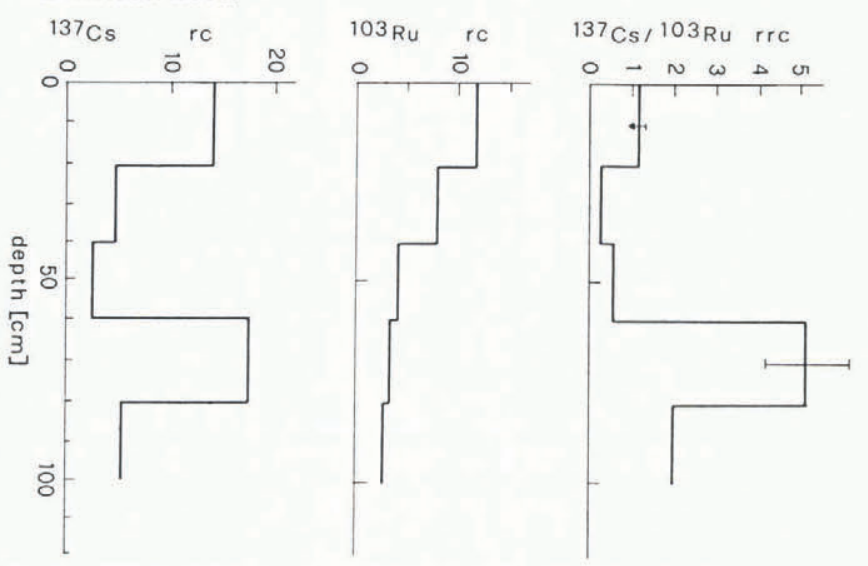

$E I R-C 5-86-33$

Fig.5. Count rates of ${ }^{137} \mathrm{Cs}$ and ${ }^{103} \mathrm{Ru}$ as a function of depth for Piz Zupò/Argient (above) and Blinnenhorn (below); rc $=$ relative count rates, rrc $=$ ratio for relative count rates. detectable nuclides, ${ }^{137} \mathrm{Cs}$ and ${ }^{103} \mathrm{Ru}$, are presented in Figure 5. At Piz Zupo/Argient, the ratio of both activities remains unchanged, bearing in mind the uncertainty of the measurement. However, at Blinnenhorn, which is at a much lower altitude and where, therefore, the influence of melt water is probably considerably greater, a distinct fractionation of the two nuclides can be observed, whereby ${ }^{137} \mathrm{Cs}$ is enriched with respect to ${ }^{103} \mathrm{Ru}$ at a depth of $0.6-0.8 \mathrm{~m}$. It appears that the distribution of ${ }^{137} \mathrm{Cs}$ is more strongly influenced by melt-water percolation than is the distribution of ${ }^{103} \mathrm{Ru}$. Gamma-spectra of the other cores are being analyzed. In addition, the sampling programme was repeated on 28 October 1986 at four selected sites (Grand Combin, Blinnenhorn, Rheinwaldhorn and Zupò/Argient), to investigate further percolation and wind-drift effects and to examine the development over time of the signal encountered.

\section{ACKNOWLEDGEMENTS}

Thanks are due to the Swiss Army for helicopter transportation and to C. Vogel and L. Tobler for the preparation of the firn samples and for collaboration during the $\mathrm{GeLi}$ measurements. J. Alean and H. Röthlisberger read and commented on the manuscript, B. Nedela prepared the drawings and P. Alean edited the English.

\section{REFERENCES}

Alean J, Haeberli W, Schädler B 1984 Snow accumulation, firn temperature and solar radiation in the area of the Colle Gnifetti core drilling site (Monte Rosa, Swiss Alps): distribution, pattern and interrelationships. Zeitschrift für Gletscherkunde und Glazialgeologie 19(2), 1983: $131-147$

Blatter H, Haeberli W 1984 Modelling temperature distribution in Alpine glaciers. Annals of Glaciology 5: 18-22

Bundesamt für Energiewirtschaft 1986 Der Unfall Chernobyl - ein Ueberblick über Ursachen und Auswirkungen. Bundesamt für Energiewirtschaft. Bern, Hauptabteilung für die Sicherheit der Kernanlagen (Bericht HSK-AN-1816).

Gäggeler H, Gunten $H$ R von, Rössler E, Oeschger $H$, Schotterer U $1983{ }^{210} \mathrm{~Pb}$-dating of cold Alpine firn/ice cores from Colle Gnifetti, Switzerland. Journal of Glaciology 29(101): 165-177

Haeberli W 1976 Eistemperaturen in den Alpen. Zeitschrift für Gletscherkunde und Glazialgeologie 11(2), 1975: 203-220

Haeberli W, Alean J 1985 Temperature and accumulation of high altitude firn in the Alps. Annals of Glaciology 6: $161-163$

Haeberli W, Schotterer U, Wagenbach D, Haeberli-Schwitter $\mathrm{H}$, Bortenschlager S 1983 Accumulation characteristics on a cold, high-Alpine firn saddle from a snow-pit study on Colle Gnifetti, Monte Rosa, Swiss Alps. Journal of Glaciology 29(102): 260-271

Jost D T, Gäggeler $\mathrm{H}$ W, Baltensperger $\mathrm{U}$, Zinder $\mathrm{B}$, Haller P 1986 Chernobyl fallout in size-fractionated aerosol. Nature 324(6092): 22-23

Kasser, P, Siegenthaler H 1985 Thickness changes of Swiss glaciers. In Haeberli W. (comp) Fluctuations of glaciers 1975-1980. (Aerial photogrammetric maps). Paris, International Commission on Snow and Ice of the International Association of Hydrological Sciences and UNESCO: $68-74$

Oeschger H, Schotterer U, Stauffer B, Haeberli W, Röthlisberger H 1978 First results from Alpine core drilling projects. Zeitschrift für Gletscherkunde und Glazialgeologie 13(1/2), 1977: 193-208

Schotterer U, Haeberli W, Good W, Oeschger H, Röthlisberger H 1981 Datierung von kaltem Firn und Eis in einem Bohrkern vom Colle Gnifetti, Monte Rosa. Jahrbuch der Schweizerischen Naturforschenden Gesellschaft. Wissenschaftlicher Teil 1978: 48-57 